Molecules 2010, 15, 8143; doi:10.3390/molecules15118143

Correction

\title{
Al-Salahi, R. Synthesis and Reactivity of $[1,2,4]$ Triazolo-annelated Quinazolines. Molecules 2010, 15, 7016-7034
}

\section{Rashad A. Al-Salahi ${ }^{1, *}$ and Detlef Geffken ${ }^{2}$}

1 Departmen of Pharmaceutical Chemistry, College of Pharmacy, King Saud University, Riyadh 11451, Saudi Arabia

2 Institute of Pharmacy, Chemistry Department, University of Hamburg, Bundesstrasse 45, 20146 Hamburg, Germany; E-Mail: geffken@chemie.uni-hamburg.de (D.G.)

* Author to whom correspondence should be addressed; E-Mail: salahi76@yahoo.com.

Received: 9 November 2010 / Accepted: 10 November 2010 / Published: 10 November 2010

The authors wish to make the following corrections to the paper published in Molecules [1]: The authorship of the paper is changed to Rashad A. Al-Salahi and Detlef Geffken. The 'Acknowledgements' section of the original publication must be taken as deleted. Finally, the 'Sample Availability' information is changed to: Compounds 5-18 are available from Detlef Geffken, University of Hamburg.

\section{References}

1. Al-Salahi, R.A. Synthesis and Reactivity of $[1,2,4]$ Triazolo-annelated Quinazolines. Molecules 2010, 15, 7016-7034.

(C) 2010 by the authors; licensee MDPI, Basel, Switzerland. This article is an open access article distributed under the terms and conditions of the Creative Commons Attribution license (http://creativecommons.org/licenses/by/3.0/). 